\title{
Early Warning: North Korean Refugees in China
}

\author{
Donald S. Rickerd
}

\begin{abstract}
Very little is known about the tragic "flood" of poverty-stricken, starving refugees from North Korea who are seeking food and safety in the People's Republic of China. This article sheds some light on their plight and the emerging refugee crisis in that part of the world.

\section{Precis}

On en sait tres peu sur la tragedie $d u$ $<<f l u x »$ de refugies affames, chasses de Coree du Nord par la pauvrete, et cherchant nourriture et securite en Republique Populaire de Chine. Lepresent article leve quelque peu Ie voile sur ce drame, et sur la crise de refuge en emergence dans cette partie du monde.
\end{abstract}

With the world's attention so focused on refugee crises in countries such as Afghanistan, Rwanda, and Yugoslavia, very little is known about, nor is much attention paid to, the thousands of refugees who have left their homes in North Korea and fled to the relative safety of the People's Republic of China (PRe).

Now, however, some reports filtering out of China suggest that Chinese authorities have become extremely concerned about the increasing influx of North Koreans, most of whom cross the Yalu River into Liaoning Province in the People's Republic of China. In China's three northeastern provinces of Liaoning, Jilin, and Heilongjiang, ithas been unofficially estimated that 200,000 to 300,000 refugees from the Democratic People's Republic of Korea (DPRK) are eking out a living. Those who are able to find work are often paid as little as onesixth of the average Chinese wage. Thus, their living conditions are extremelypoor.

Donald S. Rickerd, C.M., Q.c., is a Research Associate atthe Cen tre for Refugee Studies, York University, and President of the Zavikon Foundation.

Refuge, Vol. 18, No.2 (April 1999)
In their homeland, North Koreans suffer from a harsh political regime, extremes of climate which are especially prominent in winter, and from a pervasive famine that has caused extensive malnutrition and many deaths. They have very few opportunities to flee these difficult living conditions. To the south, the famous Demilitarized Zone (DMZ) is so heavily mined and guarded that escaping across it is extremely hazardous. A few North Koreans have fled by sea, but the main route has been towards the nearby provinces of China.

While a few diplomats and other North Korean government officials have defected via Beijing or other foreign capitals after being posted there on official business, ordinary North Koreans have been trying to escape across the border into China. In so doing, they risk being killed by their own border guards or returned to North Korea by Chinese authorities.

The DPRK has been known to deal extremely harshly with repatriated nationals who had made it to the Chinese side. Because the DPRK is so secretive, it has never admitted that its citizens have been crossing the border to China in increasing numbers. Instead, information about North Korean refugees has come from various, mostly unofficial, sources within China, supplemented by reports from South Korea which may be somewhat skewed by the continuing propaganda warfare which continues between the two Koreas.

On February 5, 1999, The Times of London reported a recent change in Chinese policy whereby North Koreans who are caught fleeing across the Yalu will no longer be treated as refugees but will be pushed back across the border, where they will face punishment by the DPRK government and a continuation of the poverty and hunger which drove them to China in the first place. Chinese authorities in a town such as Tumen have also indicated that local people who are found harbouring Koreanrefugees will be fined 5,000 yuan, an amount equal to a year's income in that area.

The PRC police have been carrying outhouse-to-house search near the border, especially the houses of ethnic Koreans legitimately living in the area who are deemed most likely to help the North Korean refugees. Recently, the South China Morning Post, published in Hong Kong, quoted one such ethnic Korean peasant living near the border as saying: "Public security officials came a month ago and said it does not matter whether they starve to death or not, no one must help any refugee." The roundups of refugees have been accompanied by other unfortunate steps taken to discourage the presence of Korean refugees. The PRC has, for example, deported DPRK women who have married Chinese or ethnic Koreans living legitimately in border areas.

Until recently, North Korean border guards were under shoot-to- kill orders with respect to escapees, but in recent months there have been reports that those harsh measures have been relaxed somewhat. Surprisingly, with border controls as strict as they are, thousands of North Koreans manage to slip unobtrusively back and forth across the border, either to trade goods for food or to obtain work illegally.

The issue of North Korean refugees has two dimensions to it. Firstly, there is the famine exacerbated by the near collapse of North Korea's economy. Secondly, there is the long-term issue of what will happen if there is a sudden upheaval in North Korea which might cause millions of refugees to leave North Korea, seeking refuge in either South Korea or in the People's Republic of China. Both countries are seriously concerned about the issue, but due to the lack of adequate resources might not be able to cope with such a catastrophe .•• 